\title{
Internal Motivation as a Factor in the Development of the Self-Direction of a Future Specialist
}

\author{
M. M. Pavliuk
}

Interregional Academy of Personnel Management, Kyiv, Ukraine

Corresponding author Email: Psycholprof@gmail.com

Paper received 16.12.17; Revised 20.12.17; Accepted for publication 22.12.17.

https://doi.org/10.31174/SEND-HS2017-146V24-08

\begin{abstract}
The article is devoted to one of the urgent problems associated with the formation of the motivation and self-direction of the future specialists. The concepts of self-direction and motivation are defined, which are one of the positive values that contribute to the manifestation of individuality and achievement of success in various spheres of life of an individual. The structure and psychological essence of motives and motivation, and types of motivation are dealt with. The results of an empirical study of external and internal motivation are presented. It is concluded that the internal motivation encourages students to independently set goals and is a source of the pursuit of personal and professional success.
\end{abstract}

Keywords: self-direction, motive, motivation, activity, self-regulation, activities, future specialists.

Relevance of research. The reform of the modern educational system in Ukraine is connected with the rapid changes in society and the demand for competitive specialists in the labor market. A qualitative training of future specialists is especially relevant in our time and provides, in the first place, the development of positive motivation to the chosen profession through a well-organized teaching and learning activity. A special place in the process of reorganizing of the educational environment is occupied by the independent work of students, in particular, the forms, methods, and techniques of its organization.

The results of the research and the experience accumulated in higher education institutions make it clear that without a systematic specially organized and focused individual work, it is impossible to become a highly-trained professional. The undeveloped skills of independent work become an obstacle on the way to further self-improvement and self-development in process of implementation of the future professional activity. That's why the independent work of students is seen as the most important component of their cognitive activities, a powerful reserve of improvement of the quality of education and strengthening of the effectiveness of the educational process.

The study of the problem of self-direction and motivation has not only philosophical but also methodological significance. Since our activities and behavior, as a rule, are not determined unambiguously, they can be induced by a wide range of mental phenomena. That is why the object and methods of studying motivation and self-direction are significantly expanding in our time and require the implementation of an integrated and systematic approach to its study. The theoretical and applied aspects of self-direction and motivation, the importance of which for psychology is difficult to overestimate, are an important component of professional competence in the process of training future professionals. The analysis of self-direction and motivation is necessary for solving a wide range of psychological problems, the leading place among which belongs to the problems of an individual's activity, its orientation, and a psychological structure of activity.

In domestic and foreign science, the nature of the learning motives has been widely studied (V. Aseev, E. Il'in) [2]. In particular, the issues of the self-direction of students in higher educational institutions draw the attention of scientists from both theoretical and methodological points of view (V. Bondar', S. Hluzman, O. Kucheriavyi). Aristova compares the traditional and innovative approaches to the classification of principles, methods, and forms of or- ganization of educational activities in the process of forming the motivation of learning; G. Letina emphasizes effective ways to preserve motivation. The motivational prerequisites of studying separate disciplines are considered (I. Krasnoholova), as well as motivation and self-direction as a means of quality training of future professionals (S. Arhangel'skij, V. Burinskij, N. Voskresenska, L. Zhuravska).

The research by A. K. Markova, E. A. Klimov, N. S. Prjazhnikov, and others prove that the psychologicallyfilled professional activity is expressed in an absolute selfdirection of the individual as a subject of work. V. A. KanKalik, L. M. Mitina, E. I. Rogov, and others emphasize compliance of self-direction of the highest level with creativity and call this level an individually independent one. At the same time, they note that for the development of pedagogical creativity, it is important to provide a maximum independence to a young teacher from the very beginning. It is better if this will be done at a stage of professional training since it is in the university that the basic qualities of the future specialist are built. A similar point of view is shared by A. A. Verbickij, L. M. Mitina, V. A. Jakunin, V. A. Baljuk, E. F. Mosin, M. A. Danilov, R. I. Ivanov, I. D. Klegeris, M. I. D'jachenko, L. A. Kandybovich, and others. Self-direction is determined by the researchers as both the quality of the personality of the professional and the way to achieve professionalism [5].

The goal of the article is to present the results of an empirical study of external and internal motivation as the basis for the development of self-direction of future professionals.

In the structure of personality, motivation takes a special place and is the main concept used to explain the driving forces of human behavior and activities. The theoretical certainty and uniqueness of views on the phenomena of motivation are still far from being complete. This, in particular, is reflected in the ambiguity of definitions of the basic concepts of this field of psychology, such as need, motive, motivation. The theoretical analysis within the activity tradition allows classifying and structuring various theoretical and methodological approaches to the analysis of problems in the field of motivation.

Motivation not only shapes (determines) an individual's activity but also permeates most of the spheres of his/her mental activity. H. Heckhausen[9] distinguished motive and motivation in the following way. The concept of motive contains, in his opinion, such concepts as need, incentive, craving, inclination, aspiration, etc. The motive is determined by the target state of the individual- 
environment relationship. Motives are formed in the process of individual development as a relatively stable evaluative attitude of a human to the environment. People differ in individual manifestations of their nature and strength of one or another motive. Human behavior at a specific point is motivated not by any or all possible motives, but those of the highest motives that are most associated with the ability to achieve the goal under given conditions (a working motive). The motive remains working, that is, participates in the motivation of behavior until the goal or conditions that have changed have been achieved and have made another motive more significant for this person.

Unlike the motive, H. Heckhausen defines motivation as instigation to act by a certain motive. Motivation is understood as the process of choosing between different possible actions, as a process that regulates and directs the action to achieve specific for this motive states and supports this orientation. Activity is said to be motivated when it is aimed at achieving the goal of a particular motive. It depends on the motivation how and in what direction different functional abilities of the person, his/her interests and inclination will be used [9].

Attempts to classify motives have been made both in foreign and in domestic psychology. At the same time, the distinction between different types of motives and their classification by many authors depend on their understanding of the essence of motive.

As mentioned earlier, the lack of differences in understanding of the concepts of motive, need, and motivation in foreign motivational psychology led to the fact that the classifications of motives in most cases coincide with the classifications of needs and motivation. Based on this, there are grounds to consider the previously analyzed needs classifications as classifications of motives. Such are the classifications by H. Murray, A. Maslow, D. McClelland.

In general, the motivation of training and learning activities of students should be related to the search for internal conditions for the growth of the effectiveness of educational activities. Therefore, one of the key means of development of the motivational sphere of a student's personality is a specially organized activity based on factors that influence the activation of the internal motivation of students.

The independent work of students is intended not only for the mastery of each discipline but also for forming the independent work skills in general: in the academic, scientific, and professional spheres, the ability to take responsibility, to solve problems on their own, to find constructive solutions and the way out of the crisis. In so doing, one should proceed from the level of independence of applicants and the requirements to the level of the graduates' self-direction.

The basic idea of controlling the independent work of students consists of the need to organize this process so that the students not only expand their knowledge gained during lectures but also master the methods of scientific learning by means of independent search, form the ability to selfeducate, develop curiosity and a taste for a creative approach in their independent work, and thus produce or improve their qualities, properties, and traits, important for a successful performance of professional functions. Thus, a properly organized independent work has not only educational but also personal and professional significance.

The internal cognitive processes are presented in the works by S. Maksymenko [4], V. Repkin [7] as a correla- tion between theoretical thinking and effectiveness of operating the theoretical knowledge, between consciousness and reflection as the ability to mirror the existence and one's self. At this level, there is a specific transformation and appropriation of methods of mastering knowledge. At the same time, the theoretical knowledge becomes part of the consciousness and influences the development of selfdirection.

In the process of learning, students take on the experience of the older generation through the direct contact with the outside world, but the acquired knowledge is gained independently.

First of all, the needs for learning as such become a derivative (from the Latin derivatus which means drawn from) of the student's learning life. The needs as an instigation to action in learning manifest in desires, attempting, and wanting to acquire theoretical knowledge. The need for education is considered by N. Talyzina as the main psychological mechanism of motivating the activities of the subject of learning and his ability to overcome difficulties. The scientist stresses that "the level of the purposefulness of learning depends on how a person is able to see and set before him/her distant, perspective, socially meaningful purposes and how much he/she is induced by realized leading motives" [8].

A characteristic feature of needs is its meaningfulness, that is, the motivation of actions. The motive is what predetermines the aspiration of a person to this, and not to any other purpose. According to H. Kostiuk's definition, "the genetically primary basis for motivating the person is his/her primary and secondary needs... These needs are recognized and experienced by the person, thereby giving rise to incentives for activities aimed at satisfaction" [3]. The motives have elements of personal orientation in their content, realized for a certain purpose. In educational activities, it is especially important to determine the conditions of manifestation and formation of motives. Motives are of a multi-faceted nature, but their main function is a conscious choice of actions to meet the need. The motive cannot become an internal stimulus to action if it has not received a subjective stimulation from a psychological phenomenon of need.

There are different classifications of the motives of learning activities. The most widespread classification is the model of motives suggested by A. Markova [5].

The first group of motives is associated with the understanding of learning out of a sense of responsibility by students, etc.; the second is determined as a cognitive need; the third is related to the habit of the regular sessions, with a desire for self-education; the fourth is connected with personal success: ambition, sense of self-worth.

The motives are classified based on how the motive is related to the goal: the first group is the motives, based on the broad societal goals that lead to understanding the social significance of educational activities, learning as a duty; the second group is the motives, which have a desire for personal success as their source, i.e. the personal meaning and value come to the foreground; the third group is motives arising from cognitive needs. As a type of activity of the learner, the main source of cognitive motives turns out to be the learning process itself [5].

The study of the motives of learning activities is given a lot of attention in both psychological and didactic studies. The developments are usually conducted in many direc- 
tions: the motives for studying in different age groups; the structure of the working mechanisms of the motives of cognition and the dynamics of their development; formation of learning motives; the study of the conditions of development of activity and self-direction in educational activity; expanding the content of the motive of learning in the context of socio-economic changes in society, etc.

It is determined that the motives of educational activities can be different, but the main motive is cognitive interest. The generalization of the signs of the motives of cognitive activity allows to determine their interrelation in all of one's actions, attitudes, and aspirations to study: 1) readiness and ability to different types of study both in practical and theoretical terms; 2) the tendency to experiment, which manifests itself in the reluctance to blindly believe, and in the desire to independently test and personally verify everything; 3) an increased intellectual activity, which is stimulated not only by the natural age-related curiosity but also by the desire to develop and demonstrate to everyone around one's abilities, and to receive a high assessment; 4) the reflection of intellectual abilities, especially the operation of the conceptual apparatus, the improved ability to use it logically and abstractly; 5) awareness of the content of the practical value of theoretical knowledge, which will be used in the future in one's professional activities.

Consequently, the formation of a stable motive as a cognitive interest requires taking into account the development of reflection. Thus, V. Davydov proves that the reflection in educational activity is the process of correlation of means of actions, which are carried out in special conditions, among which the interaction of subjects of study is crucial for the successful mastering of educational material.

According to I. Kon's definition, reflection is "the ability of the subject to overtake the position of the observer and the controller in relation to himself/herself, his/her actions and thoughts, and also implies the ability to overtake the position of the researcher in relation to another acting person, with which this subject interacts." L. Haponenko's research has proved that reflexive communication in educational activities is a psychological condition for the development of "an internal monologue, internal dialogue, internal polyphonic dialogue (pologue), which, according to the level of formation, provide verbal and nonverbal behavior according to their cultural character in external manifestations" [1].

The next factor in the development of self-direction in educational activities is the internal educational task. The introduced concept deepens its features, content, and specifics. Thus, creative thinking, which takes place in the process of solving the educational problem, is revealed on the material of various variants of the impediment of the conditions for their solution. Thus, the process of solving the learning problem is a continuous interaction of the motives of learning the new.

H. Kostiuk considers self-direction an important feature of the subject of study. "The decisive role in the assimilation of each concept belongs to the mental activity as the manifestation of the independence of the learner to determine the ways of solving the problem" [3]. The systematization of theoretical analysis allows us to generalize it schematically.

Thus, according to the results of the theoretical analysis, presented by the internal factors of the development of selfdirection in educational activities, the need for education is a key psychological mechanism that urges the student to: self-determination of the purpose of learning in the course of his/her life; determining the individual style of educational work; development of scientific solution of professional tasks. The generalization of the sphere of needs and motivation, the development of cognitive processes, effective operational methods for solving the learning problem, and the reflection of these processes create a methodological basis for the perception and mastery of professional competence.

It's traditional for Western psychology to distinguish and contrast two main types of motivation: internal (intrinsic) and external (extrinsic). The latter is quite common in Western psychology and "is almost as old as the experimental psychology of motivation itself," said H. Heckhausen. With intrinsic (or internal) motivation we are dealing when the goal is thematically homogeneous with action, thus the action is performed for the sake of its own content. With extrinsic (or external) motivation we are dealing when the action and result are the means of achieving some other goal (reward, avoidance of punishment, competition, etc.), with which this action is related not immanently, due to its nature, but in some arbitrarily assigned outwardly way.

However, recently, many psychologists have noted the conditionality of contrast between internal and external motivation. This conditionality is manifested in the fact that, on the one hand, internal motivation is always present even in the activity, which is mainly motivated externally, and on the other, any activity can be performed for the sake of something else. Indeed, it is possible to single out two types of motives that are distinguished by the nature of their semantic connection with the activity. However, firstly, any motive appears in one or another quality only in a specific, definite motivational structure. None of the motives can be called internal (creating meaning, according to A. N. Leont'ev) in general, outside of his place in the system of specific activities. Any activity must be performed not for its own sake, and any motive should be subordinated to other, external needs. In this context, J. Nuttin provides the following example: a student must perform his/her learning in order to get his/her parents' favor, but he/she must struggle for their favor to obtain their permission to study. Analyzing this example, J. Nuttin emphasizes that in this case, we have two different ratios of purpose and means, but not two fundamentally different types of motivation. Secondly, the distinction between them is that some of them have a cognitive function, while others are deprived of it. The discrepancy, as shown earlier, is related to the nature of the relationship of the subject's activity with his/her real needs. In the case when this connection is artificial, the motives are perceived as incentives, and activities - as being devoid of independent meaning and gaining it only through the motive-stimulus.

In its pure form, however, the mentioned occurs relatively infrequently. After all, activity, as already mentioned, is usually not related to one, but to a number of needs. The general meaning of a specific activity is a combination of its partial meanings, each of which reflects its attitude to any of the subject's needs that are associated with this activity directly or indirectly, in a necessary, situational, associative, or some other way. Therefore, an activity that is quite induced by external motives is as an infrequent occurrence as is the existence of the activity in which 
they are completely absent.

A. N. Leont'ev suggests, in this context, to distinguish among the needs that can give meaning to any activity, specific and non-specific. The specific need for this activity is such that is fundamentally impossible to fully implement in other activities. For example, the range of possible personal meanings of a sexual contact that is enumerated by I. $\mathrm{S}$. Kon, such meanings are connected with specific needs as the lessening of a sexual tension (relaxation), child-bearing (procreation), getting a sensual pleasure (recreation), intimate communion (communication), and the meanings that are connected with non-specific needs are self-assertion, maintaining the ritual, satisfaction of curiosity, compensation, etc. Perhaps, the reflected, alienated meaning is gained by an activity that is induced by non-specific needs.

Despite the disadvantages of the classification of motives in question, foreign psychology still maintains a clear focus on sources of motivation that serve as a basis for distinguishing different types of motivation. A striking example of such a classification is the one created by a group of authors (N. H. Leonard, L. L. Beauvais, R. W. Scholl). The latter can be considered as a model that integrates the views of various scholars on the motivation. Five sources of motivation became the basis for this classification:

1.) Internal

2.) Instrumental

3.) External self-concept

4.) Internal self-concept

5.) Goal internalization

Let's consider each of the five sources of motivation while addressing the traditional and modern classifications of motives that are found in the literature.

The first type of motivation is marked as the one that has the process itself as its source. Consequently, if a person is motivated to perform any work or behavior only for the satisfaction that he/she receives from this work or behavior, it is a motivation derived from the process. The work itself acts (influences) as a source of motivation: the one who works enjoys what he does.

According to H. Murray, this type of motivation is indicated as the needs of internal satisfaction, and as physiological needs according to A. Maslow. A similar motive is also called the internal motivation to getting pleasure (E. Deci) and the internal motivation to perform a task that does not depend on external control or awards (B. M. Staw).

The second type of motivation is related to the instrumental award. The latter motivates individuals when they feel that their behavior will lead to certain tangible results, such as payment, promotion, bonuses, etc. A similar motive or need was described by H. Murray and D. McClelland as a need for power, and as a need for security by A. Maslow.

The third type of motivation is caused by external sources: the individual is focused primarily on the others, seeking from them the confirmation of his/her traits, competencies, values. In this case, the ideal self is assimilated from the role expectations of reference groups. The individual behaves in such a way as to satisfy the expectations of members of the reference group, initially in order to be accepted by them, and after gaining that, in order to obtain the status. According to other descriptions, this motive includes the need for affiliation (D. McClelland, H. Murray), the need for love, affection, and affiliation (A. Maslow).
The fourth type of motivation has internal prerequisites. The individual is internally oriented, so he himself/herself establishes the internal standards of traits, competencies, and values, which become the basis for the ideal. Subsequently, the person is motivated toward the kind of behavior that supports these standards and allows him/her to achieve higher levels of competence. Similar motives were described by D. McClelland and H. Murray as a need for achievement, as a need for self-esteem by A. Maslow, as motivating factors by F. Herzberg, the dominant place among which is occupied by achievements in work, and as a need for growths by $\mathrm{C}$. Alderfer, which is related to the development of individual potential.

The fifth, and the last, type of motivation suggests that behavior is motivated by the internalization of the goal. Individuals learn attitudes and behaviors that are relevant to their personal values system. Each worker believes in the goal and is therefore motivated by the purpose of his team. A. Maslow described such motive as self-actualization.

Domestic psychology offers various classifications of motives. Some of them are based on the needs classification, respectively distinguishing biological and social motives. Others take the place of the stimulus as a classification basis, which actualizes the need (intrinsic and extrinsic motives). In addition, the motives are divided into personal and social, selfish and socially significant, ideological and moral, as well as collectivistic. The basis for these classifications is the attitudes of a personality, his/her morality, and orientation.

Motives are classified according to the type of activity that a person manifests: motives for communication, play, study, professional or sporting activities, etc. Another approach to the classification of motives is the one taking into account their time characteristics: situational and those that are manifested continuously or periodically.

E. P. Il'in divides the motives according to their structure: primary (abstract) - those with an abstract purpose only, secondary - those with a specific purpose; the latter are subdivided into complete (including all components that make up the structure of the motive) and reduced (those that are formed without the block of the internal filter) [2].

An interesting classification of motives is the one suggested by A. V. Petrovskij. The basis for this classification is the degree of representation of the psychological content of the motive in the mind. Accordingly, two groups of motives are singled out: conscious and unconscious. Conscious motives represent the need more or less clearly, which directly urges to action; the unconscious ones do not have such a clear representation.

Let's consider this classification in more detail. The conscious motives of behavior include interests, aspirations, and beliefs; the unconscious include attitudes and inclinations.

Interests are understood as the motives, which embody emotionally-painted cognitive needs of the individual. Interest is nothing more than an emotionally-colored intellectual selectivity; an interest arises when its object causes an emotional response. The interest combines the emotional and rational.

The correlation between these components allows the allocation of direct and indirect interests. Direct interests are connected primarily with the emotional attractiveness of the activity directed toward the corresponding object. Indi- 
rect interests relate to the outcome of the activity. The component of mind is prevailing in them. Direct and indirect interests are closely interrelated. Quantitative characteristics of interests are their wideness, depth, and stability.

When entering the university, the students do not always consciously approach the choosing of a future profession. The result is low motivation for learning, and hence the formal approach to obtaining knowledge and their independent improvement. The main motives for joining the university are: the desire to be among young students, the great social importance of the profession and the wide scope of its application, the profession's correspondence to interests and inclinations, as well as its creative possibilities. There are differences in the significance of motives among girls and boys. Girls more often appreciate the great social significance of the profession, the broad scope of its application, the opportunity to work in large cities and scientific centers, the desire to participate in students' amateur activities, a material security of the profession. Whereas boys more often note that the chosen profession corresponds to their interests and inclination. They also refer to family traditions.

In recent years, psychologists and educators have become more aware of the role of positive motivation for learning in securing a successful mastering of knowledge and skills. It was found that a high positive motivation can play the role of a compensating factor in case of insufficiently high abilities. However, this factor does not work in the reverse direction - a high level of abilities cannot compensate for the lack of a learning motive or its low level of manifestation and cannot lead to significant success in learning.

The awareness of the high significance of the motive of learning for a successful study led to the formation of the principle of a motivational provision of the educational process. The importance of this principle stems from the fact that in the process of studying at a university, the strength of the motive of learning and mastering the chosen specialty is reduced, which has been repeatedly emphasized in the studies. According to the data obtained by A. M. Vasil'kov and S. S. Ivanov during the polls of the students of the Military Medical Academy, the reasons for this are: unsatisfactory prospects of work and service, shortcomings in the organization of the educational process, conditions of life and leisure, shortcomings in educational work.

To successfully await the results of independent work of students, it is necessary: to create certain conditions and prove in a motivated way the necessity of its implementation, to methodically correctly organize an independent work; to provide a connection with future professional activities. To this end, a study was conducted which allowed to find out the peculiarities of the manifestation of external and internal motivation among future specialists, as well as the relationship between them. In addition, we were able to trace the dynamics of the students' motivation at different stages of study at a higher education establishment.

Methodology and methods of research. The sample of the study was 283 people, mostly female ( $86 \%)$, students of the metropolitan and regional higher educational institutions of Ukraine, aged between 18 and 23, average age20.8 years. The following measuring tools have been used: the Influence on the Position and Personality Motivation (PPM) test to diagnose the intrinsic and extrinsic motivation [10].

The results of the study. The external motivation is a construct that describes the determination of behavior of the subject in situations when factors that initiate and regulate his/her behavior are outside his self. The external motivation is based on rewards and punishments, and other types of external stimulation.

The internal motivation, on the contrary, is a construct that describes the determination of behavior of the subject in situations when factors that initiate and regulate his/her behavior are in the center, inside his self. Internal motivation is where the action of the subject is self-sufficient and is carried out for its own sake. The state of inner motivation is largely determined by the needs of self-determination and competence; in this condition, a person has an internal locus of causality (he/she feels that he/she is an actual factor of his/her own behavior), is aware of his/her own competence (perceives himself/herself as an effective agent in the interaction with those/that who/which surrounds $\operatorname{him} /$ her).

Table 1. Results of diagnostics of external and internal motivation according to the Influence on the Position and Personality Motivation test

\begin{tabular}{|l|c|c|c|}
\hline & $\mathrm{Me}$ & $\mathrm{M}$ & $\Sigma$ \\
\hline External motivation (PPM) & 3.71 & 3.71 & 0.57 \\
\hline Internal motivation (PPM) & 3.90 & 3.97 & 0.48 \\
\hline
\end{tabular}

To measure internal and external motivation, the Influence on the Position and Personality Motivation (PPM) test has been applied [10]. The results of external and internal motivation diagnostics are shown in the tables...

The manifestation of the indicators of internal motivation is statistically significantly higher than those of external motivation (according to the Wilcoxon signed-rank criterion; $\mathrm{Z}=-6.124 ; \mathrm{p} \leq 0.001)$.

Table 2. External and internal motivation and a year of study

\begin{tabular}{|l|c|c|c|c|c|c|}
\hline \multirow{2}{*}{ Troup Median, Me } & \multicolumn{3}{|c|}{ Kruskal-Wallis H-test } \\
\cline { 2 - 8 } & 1 st year & 3d year & 5 th year & $\chi^{2}$ & df & p \\
\hline External motivation (PPM) & 3.85 & 3.68 & 3.75 & 1.667 & 2 & 0.435 \\
\hline Internal motivation (PPM) & 3.88 & 4.10 & 3.95 & 4.934 & 2 & 0.085 \\
\hline
\end{tabular}

A measure of external motivation does not change during the study, and an internal motivation manifestation statistically significantly changes $(p \leq 0.1)$ : rises from the first to the third year $(\mathrm{U}=510$;

$\mathrm{p} \leq 0.05)$ and falls from the third to the fifth $(\mathrm{U}=869 ; \mathrm{p}$ $\leq 0.1)$.

Statistically significant differences between the levels of manifestation (table...) of external and internal motivation is not established.

Table 3. Level of manifestation of external and internal motivation

\begin{tabular}{|l|c|c|c|}
\hline \multirow{2}{*}{} & \multicolumn{3}{|c|}{ Manifestation level (\% of students) } \\
\cline { 2 - 4 } & Low & Medium & High \\
\hline External motivation (PPM) & 10.9 & 75.1 & 14.0 \\
\hline Internal motivation (PPM) & 11.8 & 72.9 & 15.4 \\
\hline
\end{tabular}


Between the interval indicators of internal and external motivation, a significant positive correlative relationship was observed $\left(\mathrm{r}_{\mathrm{s}}=0.233 ; \mathrm{p} \leq 0.001\right)$, as well as between the levels of manifestation of internal and external motivation $\left(\chi^{2}=28.096 ; \mathrm{df}=4 ; \mathrm{p} \leq 0.001\right)$. Thus, internal and external motivations not only do not exclude each other but rather are interrelated characteristics and are together responsible for such a personality and activity feature as motivatedness.

Conclusions. Due to internal motivation regarding selfdirection, the student attains: 1) abilities to concerted activity as signs of perceived self-regulation in educational activities; 2) ability to initiation of systematization and generalization of theoretical material presented in the academic discipline; 3 ) ability to build an educational cooperation in exchange and enrichment of mediation of theoretical material in practice.

The development of the motivation of students' independent work is a key to strong knowledge, promotes selfimprovement, self-fulfillment, and self-expression, as well as cooperation between the teacher and the students. The formation of motivation is possible provided: the utility of work performed; introduction of active teaching methods in the educational process; use of the motivating factors of knowledge control; encouraging the students for their success in learning and creative activity. Motivation is successful only when a person succeeds in linking the goal with personal values. Various tasks suggested for independent study and evaluation points give the students the opportunity to track their own successes.

Thus, determining the internal motivation of students for self-study is based on the process of acquiring knowledge and skills. An important condition for the development of the internal motivation of a modern student is the personality of the teacher and his attitude to work. That is, the teacher himself should be an example and stimulate his need for learning. The cooperation and mutual understanding between the teacher and the student have been and still are the main driving force in the formation of motivation to study.

\section{ЛІТЕРАТУРА}

1. Гапоненко Л.О. Рефлексія як умова розвитку особистості: монографія / Лариса Олександрівна Гапоненко. - Дніпропетровськ : Пороги, 2009. - 175 с.

2. Ильин Е. П. Мотивация и мотивы / Е. П. Ильин - СПб: Издательство «Питер», 2000. -512 с.

3. Костюк Г.С. Навчально-виховний процесс i психічний розвиток особистості / Григорій Силович Костюк. - К. : Радянська школа, 1989. - 608 с.

4. Максименко С.Д. Психологічні та організаційні умови запровадження європейських стандартів вищої освіти в Україні / С.Д. Максименко // Вища освіта України у контексті інтеграції до європейського освітнього простору : III Міжнародна науково- практична конференція (27-29 листопада 2008). - К. - С. 95-104.

5. Маркова А.К. Формирование мотивации учения / А.К.Маркова, Т.А. Матис, А.Б.Орлов. - М. Просвещение,

1990. - $192 \mathrm{c}$.

6. Павлюк М.M. Психологія мотивації: навчальнометодичний посібник- // М.М. Павлюк Житомир: Вид-во ЖДУ ім. І. Франка, 2016. - 266 с.

7. Репкин В.В. Строение учебной деятельности / В.В. Репкин // Вестник Харьков. ун-та. - 1976. - № 132. - Серия : Психология. - Вып. 9. - С. 10-16.

8. Талызина Н.Ф. Управление процессом усвоения знаний / Н.Ф. Талізина. - М. : МГУ, 1975. - 343 с.

9. Хекхаузен Х. Мотивация и деятельность // Х. Хекхаузен СПб.: Питер; М.: Смысл, 2003 - 860 с.

10. Энциклопедия психодиагностики. Психодиагностика детей. Редактор-составитель энциклопедии Д.Я. Райгородский. - Самара: Издательский Дом «Бахрах-М», 2008. - 624 с.

\section{REFERENCES}

1. Haponenko, L. O. (2009) Reflection as a condition for the development of personality, Monograph, Haponenko Larysa Oleksandrivna, Porohy, Dnipropetrovsk, Ukraine.

2. Il'in, E. P. (2000), Motivacija i motivy [Motivation and motives], Piter, St. Petersburg, Russia.

3. Kostiuk, H. S. (1989), Navchalno-vykhovnyi protsess $i$ psykhichnyi rozvytok osobystosti [The educational process and mental development of personality], Soviet school, Kyiv, Ukraine.

4. Maksymenko, S. D. (2008), Psychological and organizational conditions for the implementation of European higher education standards in Ukraine, Vyshcha osvita Ukrainy $u$ konteksti intehratsii do yevropeiskoho osvitnoho prostoru: III Mizhnarodna naukovo-praktychna konferentsiia [Higher Education of Ukraine in the Context of Integration into the European Educational Space. Conference proceedings of the 3d International Research-to-Practice Conference], Kyiv, November 27-29, 2008, pp. 95-104.
5. Markova, A. K., Matis, T.A., Orlov, A.B. (1990), Formirovanie motivacii uchenija [The Formation of Learning Motivation], Prosveshhenie, Moscow, Russia.

6. Pavliuk, M. M. (2016), Psykholohiia motyvatsii [Psychology of Motivation], Educational Manual, Publication of Zhytomyr Ivan Franko State University, Zhytomyr, Ukraine.

7. Riepkin, V. V. (1976), Stroenie uchebnoj dejatel'nosti [The structure of educational activity], Visnyk Kharkiv University, no. 132, Psihologija book series, issue 9, pp. 10-16.

8. Talyzina, N. F. (1975), Upravlenie processom usvoenija znanij [Management of Knowledge Acquisition Process], MSU, Moscow, Russia.

9. Heckhausen, H. (2003), Motivacija i dejatel'nost' [Motivation and Activity], Piter, St. Petersburg, Smysl, Moscow, Russia.

10. Rajgorodskij, D. Ja. (2008), Compiling Editor, Ehnciklopediya psihodiagnostiki. Psihodiagnostika detej [Encyclopedia of Psychodiagnostics. Psychodiagnostics of Children], Bahrah-M Publishing House, Samara, Russia.

\section{Внутренняя мотивация как фактор развития самостоятельности будущего специалиста}

\section{М. М. Павлюк}

Аннотация. Статья посвящена одной из актуальных проблем, связанных со становлением мотивации и самостоятельности будущего специалиста. Определено понятие самостоятельности и мотивации, являются одними из положительных ценностей, которые способствуют проявлению индивидуальности и достижению успешности в различных сферах жизнедеятельности личности. Рассмотрена структура и психологическую сущность мотивов и мотивации, виды мотивации. Представлены результаты эмпирического исследования внешней и внутренней мотивации. Сделан вывод о том, что внутренняя мотивация побуждает студентов к самостоятельной постановке целей и является источником стремление к личному и профессиональному успеxy.

Ключевые слова: самостоятельность, мотив, мотивация, активность, саморегуляция, деятельность, будущие специиалистьл. 